\title{
OTÁZKA NÁVRATU NĚKOLIKA FYZIKŮ NĚMECKÉ NÁRODNOSTI DO ČESKOSLOVENSKA PO DRUHÉ SVĚTOVÉ VÁLCE
}

\author{
EMILIE TĚŠÍNSKÁ
}

\section{THE ISSUE OF RETURN OF SEVERAL PHYSICISTS OF GERMAN NATIONALITY INTO CZECHOSLOVAKIA AFTER THE SECOND WORLD WAR}

This contribution presents and briefly comments upon several period documents which bring up and discuss the issue of possible return to Czechoslovakia of several physicists of German nationality, namely Philipp Frank, Reinhold Fürth, Georg Placzek, Marcel Schein, and Kurt Sitte. These documents also deal with the issue of their potential position at post-war Czechoslovak universities and possibility of lecturing.

Keywords: physicists - German scientists - Second World War - Philipp Frank - Reinhold Fürth - Georg Placzek - Marcel Schein - Kurt Sitte

DOI: $10.14712 / 23365730.2018 .29$

\section{Úvod}

V př́íspěvku je představeno a stručně komentováno několik dobových dokumentů, v nichž byla nastolena a řešena otázka návratu do Československa a uplatnění ve výuce na československých vysokých školách po druhé světové válce fyziků německé národnosti Philippa Franka, Reinholda Fürtha, Georga Placzeka, Marcela Scheina a Kurta Sitteho. Předkládaný materiál evokuje řadu závažných otázek, které však z důvodů omezeného rozsahu tohoto prríspěvku ponecháváme otevřené pro př́padnou další diskusi a historické bádání, stejně jako pojednání o širším historickém kontextu a stávající historiografické produkci k otázce vědecké emigrace v obecněǰš́ rovině.

\section{Dopis Guida Becka prezidentu Edvardu Benešovi}

Dopisem z 29. června 1946 se na prezidenta Československé republiky Edvarda Beneše obrátil profesor Guido Beck, toho času působící na univerzitě v Córdobě v Argentině. Dopis byl napsán kostrbatou češtinou na hlavičkovém papíre Associación física Argentina. Začínal oslovením „Vážený pane presidente“ a po úvodních odstavcích, nastiňujících motivaci pisatele, přšel k meritu věci: 
„Dovoluji si tímto dopisem upozorniti na V. E. $k$ tomu, že Československá republika vzhledem $k$ akademickému personálu ještě čitá reservu, kterou se, pokud vím, doposud nezabývala - totiž emigrací vědátorů, která jest tak významnou, že nevyhnutelně pražská universita po dobu několika desítiletí utrpí citelnou mezeru, i když nejlepši vůle a snaha se bude zabývati pokračováním tradice.

Jest jasno, že není možno povolati veškeré tyto vědátory opět do Prahy, jelikož nejvýznamnějš́ z nich již pracují v zahraničnich universitách s podklady, kteréjim české university okamžitě poskytnouti nemohou.

Též snad není vhodno, z různých důvodů, toho neb onoho učence uplatniti na českých universitách.

Považuji za svoji povinnost při nejmenším zaslati seznam jmen oněch všeobecněv těchto kruzích známých védátori̊ z mého oboru - physiky $k$ Vaší disposici, pane presidente, doufajic, že vám umožni zaslati jej ku prohlídce a kompetentnímu studiu.

Jest $m[\mathrm{n}]$ ě ovšem jasno, že z politického stanoviska tento problém v tomto okamžiku musí vyvoditi velké překáǎky a dovoluji si podotknouti, že neni okamžitá nutnost řešeni tohoto problému. Taktéž podotýkám, že tento problém v Československé republice nemožno řešiti pouhou administrativní rutinou v ministerstvu školství.

Během svého pobytu v Praze pozoroval jsem nedostatečnou podporu ministerstvem školství na všech vysokých školách, jímž trpěli stejnou měrou veškeré školy tehdejší doby.

Takový nedostatek může býti odstraněn velmi pomalým tempem, avšak význam problému vědeckého badání během poslednich let v zemích industriálně vyspělých, stal se též v mém oboru, ve physice, tak očividným, takže rožrešeni se stalo nutností.

S př́ním, aby vysoké školy Vaši země se štastně vyvinuly, račte přijmouti, pane presidente, výraz mé hluboké úcty. Prof. Dr. Guido Beck v. r.“

$\mathrm{K}$ dopisu byl připojen „Seznam československých fysiků v zahraničl" s těmito jmény a kontaktními údaji: „1) Philipp Frank, Department of Physics, Harvard University, Cambridge, Mass. U.S.A; 2) Reinhold Fürth, Department of Physics, University of Edinburgh, Edinburgh, Great Britain; 3) Jiř Placzek, Department of Physics, Cornell University, Ithaca, N.Y., U.S.A.; 4) Marcel Schein, Department of Physics, University of Chicago, Chicago Ill., U.S.A.; 5) Kurt Sitte, Department of Physics, University of Manchester, Manchester, England." 1

Z úvodních odstavců dopisu vyplývá, že Guido Beck byl k jeho napsání iniciován zprávami o ztrátách, jež utrpěly československé vysoké školy a vědecká obec za války a s nimiž se po válce jen obtížně vyrovnávaly. Zmiňoval se konkrétně o zasedání Society for Visiting Scientists v Londýně 1 . února 1946, kterého se zúčastnila československá delegace vedená ministrem zahraničních věcí Janem Masarykem. Projev o české vědě za okupace a jejím poválečném stavu zde přednesl rektor Karlovy univerzity Jan Bělehrádek. Člen exilové vlády a mimořádný vyslanec $\mathrm{v}$ Londýně Jaroslav Císař zde vystoupil s projevem o historii české vědy. Na zasedání byla tehdy př́tomna řada osob z londýnských vědeckých kruhů a dalších - britských i zahraničních - univerzit. ${ }^{2}$

1 Archiv Univerzity Karlovy (dále AUK), fond Př́rodovědecká fakulta Univerzity Karlovy (dále f. PřF UK), k. 23, i. č. 209. Citováno podle opisu dopisu.

2 Zasedání se konalo v době prvního poválečného valného shromáždění Spojených národů v Londýně (10. 1. 14. 2. 1946). Krátkou zprávu o zasedání přinesly Svobodné noviny: „V pátek [1. února] byla v Londýně schůze 
O této cestě do Anglie referoval rektor Bělehrádek ve schůzi Akademického senátu Karlovy univerzity 15. března 1946. Informoval o existenci Společnosti na ochranu perzekuovaných vědců (Society for Protection of Science), která podporuje asi dvacet pět profesorů bývalé pražské německé univerzity. Uvedl, že generální sekretář společnosti při jednání s ním poukázal na to, že vzhledem k ubývajícím finančním prostředkům společnosti by bylo záhodno uvažovat o repatriaci těchto vědců, ,kteři se však nechtějí vrátit, tvrdice, že nemají zaručeno ani čsl. státní občanství, ani pensi“. Bělehrádek odpověděl, že u osob, které prokážou negativní postoj proti nacismu, se dá udělení československého státního občanství a přiznání penze očekávat, „př́padně i zařazení do knihoven, úřadů a snad $i$ v některých odvětvích národního průmyslu jako poradci; nelze ovšem zř́diti pro tyto profesory ústavy nové ani nelze tolik německy mluvících profesorů privésti do stavu universitních profesorü university Karlovy“. O jednání informoval ministra Zdeňka Nejedlého, který jeho postoj schválil a zároveň doporučil, aby věc - vzhledem k její důležitosti - projednal ještě s ministerským předsedou Zdeňkem Fierlingerem. ${ }^{3}$

Dodejme, že Guido Beck v úvodu dopisu prezidentu Benešovi citoval také pietní vzpomínku na lidské oběti nacistické okupace z řad československých fyziků, která byla koncem března 1946 uveřejněna v anglickém časopise Nature. Vyjádřil hluboký soucit jmenovitě s tragickou smrtí profesora experimentální fyziky Karlovy univerzity Václava Dolejška, kterého „,v Praze poznal“ a jehož práci „velmi obdivoval“.4

\section{Autor dopisu Guido Beck}

Guido Beck (1903-1988) se narodil v Liberci, v německé židovské rodině. Jeho otec byl obchodník, v Liberci vlastnil velkoobchod s uhlím. V roce 1908 rodina přesídlila do ciziny. ${ }^{5}$ Obecnou školu a čtyřri trrídy reálného gymnázia absolvoval ve Švýcarsku, v Curychu. V letech 1921-1925 pokračoval ve studiu se zaměřením na fyziku na univerzitě ve Vídni. ${ }^{6}$ Po studiích působil nejprve ve Švýcarsku, v Bernu. V roce 1927 odjel do Německa, kde po čtyřri roky zastával místo asistenta u Wernera Heisenberga na univerzitě v Lipsku. Ustanovení asistentem v Lipsku G. Beckovi vypršelo na jaře 1932. Nějaký čas pak pracoval u Nielse Bohra v Ústavu teoretické fyziky na univerzitě v Kodani. Vyhlídky na akademickou kariéru v Německu pro něho zhatil nástup Adolfa Hitlera k moci. Také možnosti získat

zástupců vědy různých národů a mluvilo se tam o situaci čs. vědy, o jejím utrpení za německé okupace a o cestách a prostředcích, jež by dopomohly k její obnově.“ Svobodné noviny 2/1946, 3. 2. 1946, s. 1.

3 AUK, fond Akademický senát (dále f. AS UK), zápis o III. (II. řádném) zasedání akademického senátu, které se konalo 15 . března 1946, k. 45 , i. č. 662, s. 7 a 11-12.

4 Václav Dolejšek (1895-1945) pracoval v oboru rentgenové spektroskopie, zemřel 3. ledna 1945 v Malé pevnosti Terezín na následky vězení. Autorem zprávy byl Vladimír Vand, někdejší Dolejškův doktorand, který působil za války ve Velké Británii. Srov. Vladimír VAnd, Prague Conference on the Use of X-Rays in the Metal Industries, 28. 11. - 1. 12.1945, Nature 157, 1946, No. 3987 (30 March 1946), s. 415-416. Vand uveřejnil v Nature následně také Dolejškův nekrolog: Vladimír VAnd, Dolejšek, V. - Obituary, Nature 157, 1946, No. 3989 (13 April 1946), s. 471-472.

5 Státní oblastní archiv v Litoměřicích, Státní okresní archiv Liberec, Evidence obyvatelstva Liberec, Beck Josef; Národní archiv Praha (dále NA), e-badatelna, Matriky židovských náboženských obcí v českých krajích, (1735) 1784-1949 (1960), židovská obec Reichenberg.

6 Studium zakončil doktorátem z teoretické fyziky u profesora H. Thirringa. Archiv der Universität Wien, fol. Beck Guido, Phil PA, Sch. 39, fol. 1-6, č. 105. 
trvalý post u N. Bohra byly omezené. Dočasným útočištěm se tak Guidu Beckovi v letech 1932-1934 stala Praha (k tomuto krátkému a nejasnému úseku v jeho profesní kariéře se vrátíme v závěrečném dovětku). V roce 1934 absolvoval kratší studijní pobyt v USA, poté působil v letech 1935-1937 v Sovětském svazu, na univerzitě a námořním učilišti v Oděse. V roce 1938 nalezl útočiště v Ústavu atomové fyziky na univerzitě v Lyonu. Po obsazení Francie v roce 1942 uprchl do Portugalska a po krátkém pobytu na tamních univerzitách zamíril do Argentiny, odkud dostal pozvání a nabídku na spolupráci v teoretické fyzice od ředitele astrofyzikální observatoře na univerzitě v Córdobě R. E. Gavioly. ${ }^{7}$ Spolu s Gaviolou se pak podílel také na založení Argentinské fyzikální společnosti. V Jižní Americe zůstal i po válce (působil v Argentině a v Brazílii). V zimním semestru 1971/1972 byl pozván jako hostující profesor teoretické fyziky na univerzitu ve Vídni. Zemřel při automobilové nehodě v Riu de Janeiru. ${ }^{8}$

\section{Pětice fyziků z prílohy Beckova dopisu}

S pěti fyziky, které uvedl na seznamu připojeném k dopisu prezidentu Edvardu Benešovi, se Guido Beck osobně znal. Je ovšem otázkou, zda s nimi svou iniciativu konzultoval a zda on sám uvažoval o návratu do poválečného Československa. Jejich osudy si byly v mnohém podobné. Byli víceméně krajané narození ještě v rakousko-uherském mocnár̆ství, německé národnosti a židovské víry. Jejich profesní dráhy se v meziválečném období protnuly geograficky i v oblastech odborného zájmu a profesní působnosti. Meziválečné Československo pokládali vesměs za svou vlast, s níž byli spojeni rodinnými kořeny nebo dlouholetou akademickou kariérou (v př́padě Philippa Franka). K odchodu co ciziny je vedly, byt' v různých etapách jejich života, profesní kariéra, existenční důvody a hrozba nacistické perzekuce. Druhá světová válka zasáhla do jejich osobního života i profesní kariéry. I když těžké období války všichni přežili, po obnovení mírových poměrů byla většina z nich postavena před nové rozhodování o dalším životě a profesní kariéře.

Philipp Frank (1884-1966) byl ve vztahu k ostatním uvedeným fyzikům představitelem generace jejich učitelů. Původem byl Rakušan. Narodil se v roce 1884 v Badenu u Vídně, ve Vídni absolvoval středoškolská a univerzitní studia a začátek akademické kariéry. V letech 1912-1938, tj. plných dvacet šest let, však zastával profesuru teoretické fyziky na Německé univerzitě v Praze, kde byl v roce 1912 jmenován mimořádným profesorem (jako nástupce Alberta Einsteina) a v roce 1917 řádným profesorem. Na podzim 1938 odjel na přednáškové turné po univerzitách ve Spojených státech amerických, ze kterého se do okleštěného a ohroženého Československa již nevrátil. V USA zakotvil na Harvardově univerzitě v Cambridgi ve státě Massachusetts. ${ }^{9}$

Reinhold H. Fürth (1893-1979) se narodil v Praze v rodině advokáta. Po rodičích byl židovského vyznání. V letech 1912-1916 studoval matematiku a fyziku na Německé

7 Ramón E. Gaviola (1900-1989) studoval v letech 1920-1926 v Německu, poté působil nějaký čas v USA. Byl prvním předsedou Argentinské fyzikální společnosti. <http://nuestrotiempobiografias.blogspot.cz/2009/10 /ramon-enrique-gaviola-nacio-en-la.html > (16. 1. 2018).

8 <https://en.wikipedia.org/wiki/Guido_Beck> (16. 1. 2018).

9 Podrobněji např. Emilie TĚšínské, Fränk Philipp, in: Biografický slovník českých zemí, XVIII, Fo-Fr, Praha 2015. 
univerzitě v Praze. Studia zakončil v červnu 1916 doktorátem filozofie. Od školního roku 1918/1919 působil v Ústavu pro teoretickou fyziku, vedeném Philippem Frankem, nejprve jako vědecká pomocná síla, pak jako asistent. V roce 1919 se na Německé univerzitě v Praze habilitoval pro fyziku, 1927 byl jmenován mimořádným a 1933 rádným profesorem experimentální fyziky, od školního roku 1931/1932 zde převzal vedení Fyzikálního ústavu. Na konci zimního semestru 1938/1939 byl z učitelského sboru Německé univerzity v Praze vyloučen $\mathrm{z}$ rasových důvodů, stejně jako ostatní pedagogové židovské víry. $\mathrm{Z}$ ohroženého Československa emigroval do Velké Británie. Za války působil na univerzitě v Edinburghu. V letech 1947-1961 přednášel teoretickou fyziku na Birkbeck College Londýnské univerzity. Zemřel v Londýně.

Georg Placzek (1905-1955) se narodil v Brně, rovněž v židovské rodině. Jeho otec byl průmyslník, vlastnil továrnu v nedalekých Alexovicích. Georg Placzek maturoval v roce 1924 na německém státním gymnáziu v Brně. Poté se zapsal ke studiu matematiky a fyziky na univerzitě ve Vídni. Ve školním roce 1925/1926 studoval na Př́rodovědecké fakultě Německé univerzity v Praze. ${ }^{10}$ Studium zakončil ve Vídni v červenci 1928 doktorátem z fyziky. Podobně jako Guido Beck prošel po studiích řadou stáží u předních evropských fyziků, mj. Wernera Heisenberga v Lipsku a Nielse Bohra v Kodani. I on působil určitou dobu v tehdejším Sovětském svazu, a sice ve Fyzikálně-technickém ústavu v Charkově v letech 1933/1934 a 1935-1936, kde spolupracoval s Lvem Davidovičem Landauem. ${ }^{11}$ Po následných krátkých pobytech v Římě, Kodani a Paříži odjel v roce 1939 do USA. Pracoval na Cornellově univerzitě v Ithace, ve státě New York. Za války a bezprostředně po válce byl zapojen do amerického jaderného programu. Od roku 1953 působil opět v Evropě, přednášel na univerzitách v Miláně a v R Rímě. Zemřel v Curychu. ${ }^{12}$

Marcel Schein (1902-1960) se narodil v obci Trstena v oblasti Oravy na Slovensku. Byl také židovského vyznání. Pocházel zřejmě z nemajetných poměrů. Maturoval v červenci 1920 na evangelickém lyceu v Kežmarku. V ř́ijnu 1920 se zapsal ke studiu na Př́rodovědecké fakultě Německé univerzity v Praze, kde však studoval jen po jeden semestr. ${ }^{13} \mathrm{Ve}$ studiích pokračoval na univerzitách ve Vídni, Würzburku a Curychu, kde získal v roce 1927 doktorát a nastoupil na místo asistenta. Po roční stáži na univerzitě v Chicagu se v roce 1931 na univerzitě v Curychu habilitoval pro teoretickou fyziku. V roce 1934 príijal profesuru experimentální fyziky na univerzitě v Oděse, kde působil do roku 1937. V roce 1938 odjel na pozvání A. H. Comptona znovu do USA; působil na univerzitě v Chicagu. Hlavní oblastí jeho odborného zájmu po odchodu do USA bylo studium kosmického záření. Také on byl za války zapojen do amerického jaderného programu. ${ }^{14}$

10 AUK, fond Německá univerzita v Praze (dále f. NU), Př́rodovědecká fakulta (dále PřF), Katalogy posluchačů, ZS 1925-1926, řádní posluchači, pořadové č. 232; LS 1926, řádní posluchači, pořadové č. 222.

11 Lev Davidovič Landau (1908-1968), ruský fyzik židovského původu. Po završení studií na Leningradské státní univerzitě v roce 1929 pobýval 1,5 roku v západní Evropě jako stipendista Rockefellerovy nadace, mj. v Ústavu teoretické fyziky N. Bohra v Kodani. Od roku 1932 působil v Charkově ve Fyzikálně-technickém ústavu a na univerzitě jako vedoucí oddělení teoretické fyziky. S ústavem N. Bohra v Kodani byl nadále v kontaktu. V roce 1937 přešel do Ústavu teoretických problémů AV SSSR v Moskvě, v jehož čele stál P. L. Kapica.

12 Podrobněji např. Jan FISCHER, Georg Placzek (1905-1955), Československý časopis pro fyziku (dále ČČF) A 35, 1985, s. 607-611; Aleš GotTVALD, Kdo byl Georg Placzek (1905-1955), ČČF 55, 2005, s. 275-287.

13 AUK, f. NU, PřF, Katalogy posluchačů, ZS 1920-1921, č. 171.

14 Bruno Rossi, Prof. Marcel Schein, Nature 186, 1960, No. 4720 (April 30, 1960), s. 355-356; Universität Zürich, Universitätsarchiv, Matrikeledition, No. 29627, Schein Marcel, dostupné na <www.matrikel.uzh.ch> (16. 1. 2018). 
Kurt Sitte (1910-1993) pocházel stejně jako G. Beck z Liberce, byl však o sedm let mladší. V Liberci vystudoval střední školu, jeho otec byl ředitelem tamní reálky. Pokračoval studiem matematiky a fyziky na Německé univerzitě v Praze, kde byli jeho profesory Philipp Frank a Reinhold Fürth. Od školního roku 1931/1932 působil ve Fyzikálním ústavu vedeném R. Fürthem, nejprve jako vědecká pomocná síla, poté jako asistent. Zde vypracoval doktorskou disertaci. Ve Fyzikálním ústavu Německé univerzity v Praze spolupracoval pak v letech 1932-1934 s Guidem Beckem, výsledkem bylo několik společných publikací z jaderné fyziky. ${ }^{15}$ V roce 1935 se R. Fürth na Německé univerzitě v Praze habilitoval pro fyziku. Koncem zimního semestru 1938/1939 byl z řad pedagogů univerzity vyloučen pro angažovanost v klubu „Die Tat“. S manželkou se chystali k emigraci do Velké Británie, odjet však nestačili. Za okupace byl vězněn a deportován do koncentračního tábora (nejprve Dachau, pak Buchenwald). Koncentračními tábory prošla i jeho manželka. Do Velké Británie odjeli po válce, v prosinci 1945. Jako jediný z pětice fyziků uvedených na Beckově seznamu tak Kurt Sitte neprožil válku v emigraci, ale odjel do zahraničí až po ní s cílem pokračovat ve vědecké práci. V letech 1946-1948 působil na univerzitě v Manchesteru, kde se zabýval kosmickým záŕením. Ve Velké Británii nezakotvil, do Československa se však natrvalo již nevrátil. ${ }^{16}$

Dodejme, že Philipp Frank, Reinhold Fürth a Otto Blüh byli od r. 1935 členy Jednoty československých matematiků a fyziků. Fürth i Blüh, kteří za války působili v emigraci ve Velké Británii, se stali také členy Sdružení československých badatelů v zahraničí, jež se ustanovilo při československé exilové vládě v Londýně. ${ }^{17}$

\section{Stanovisko Kanceláře prezidenta Republiky, Ministerstva školství a osvěty a akademických sborů československých vysokých škol k iniciativě Guida Becka}

Kanceláŕ prezidenta republiky postoupila dopis Guida Becka 12. ř́inna 1946 Ministerstvu školství a osvěty (dále jen ministerstvo) se žádostí o vyjádření. ${ }^{18}$ Ministerstvo 31 . ledna 1947 odpovědělo, že dopis byl předložen ,,profesorským sborům přirodovědeckých fakult Karlovy a Masarykovy univerzity a vysokých škol technického smèru k úvaze a vyjádřeni" a jejich stanovisko bude kanceláři sděleno, jakmile je ministerstvo obdrží. ${ }^{19}$

15 Guido BeCK - Kurt SitTe, Zur Theorie der $\beta$-Zerfalls, Zeitschrift für Physik 86, 1933, s. 105-119; тíž, $\beta$-emission of positive electrons, Nature 133, 1934, s. 722; тíž, Bemerkung zur Arbeit von E. Fermi: , Versuch einer Theorie der $\beta$-Strahlen“, Zeitschrift für Physik 89, 1934, s. 259-260.

16 Podrobněji např. Emilie TĚšínsKÁ, Zlomek pisemné pozůstalosti profesora fyziky na Německé univerzitě v Praze Reinholda Fürtha, Práce z dějin Akademie věd 9, 2017, s. 39-49.

17 Zdeněk Pousta, Jaroslav Císař. Astronom a diplomat v Masarykových službách, Praha 2016, s. 260, poznámka 470.

18 Archiv Kanceláře prezidenta republiky (dále AKPR), fond Kancelář prezidenta republiky (dále f. KPR), k. 306, i. č. 1644/L, sign. D4129/47 (kopie dopisu).

19 Tamtéž, dopis MŠO č. A-228.293/46-VI/5. 


\section{Prírodovědecká fakulta Karlovy univerzity}

Př́ípis ministerstva zaslaný v uvedené věci děkanství Přírodovědecké fakulty Karlovy univerzity byl datován 22. listopadu 1946. Ministerstvo žádalo, aby věc byla projednána ve schůzi profesorského sboru a stanovisko bylo ministerstvu urychleně oznámeno. ${ }^{20}$

Děkan fakulty Julius Komárek postoupil přípis profesorům fyziky Viktoru Trkalovi a Augustu Žáčkovi k vypracování návrhu pro profesorský sbor. V profesorském sboru byla záležitost projednána ve schůzi 12. prosince 1946. Na návrh profesora Žáčka bylo jednomyslně přijato usnesení, které děkan fakulty tlumočil ministerstvu 3. ledna 1946 slovy:

„Všichni v seznamu uvedeni fysikové pưsobili před válkou na býv. pražské něm. universitě. Z nich pouze prof. R. Fürth, t.č. působicí na universitě v Edinburghu, projevil ochotu věnovati své sily a védomosti československému státu. Ostatni podobné ochoty neprojevili.

$Z$ uvedených fysikù, kromě prof. $R$. Fürtha, nemá žádný toho významu, aby s jeho povoláním mohlo býti počitáno.

Vzhledem k tomu, že v porevolučni době se usnesl sbor děkanů v čele s rektorem Karlovy university na tom, že za profesory na Karlovu universitu mohou býti povolávány jen osoby, které již v r. 1910 se hlásily k české národnosti, nemůže býti uvažováno o povolání prof. R. Fürtha, jakož i ostatnich fysiků v seznamu uvedených (Frank, Placzek, Schein, Sitte) na zdejši fakultu.

$Z$ uvedených di̊vodì usnesl se prof. sbor doporučiti, aby prof. R. Fürth byl pozván ke konáni několika přednášek o pokrocích fysiky na zdejši fakultě.“

K závěrečnému doporučení děkan dodal, že návrh na pozvání profesora Reinholda Fürtha k přednáškám na Př́rodovědecké fakultě Karlovy univerzity byl ministerstvu předložen již 19. prosince 1945, byl však výnosem ministerstva z 11. dubna 1946 zamítnut. ${ }^{21} \mathrm{~K}$ př́ípisu byl připojen plný text návrhu vypracovaného profesorem Žáčkem.

\section{Návrh a stanovisko profesora Augusta Žáčka}

Návrh profesora A. Žáčka, podaný na hlavičkovém papíře Fyzikálního ústavu Univerzity Karlovy, byl datován 19. prosince 1946. Žáček v něm věnoval pozornost de facto jen osobnosti Reinholda Fürtha. O Philippu Frankovi se nezmínil. Fyziky Kurta Sitteho, Marcela Scheina a Georga Placzeka, kteří představovali mladší generaci a o jejichž působení za války mu zjevně nebylo nic známo, označil za „nemajici toho významu, aby s jejich povoláním mohlo býti počitáno“. Reinholda Fürtha charakterizoval jako výborného fyzika, znamenitého vysokoškolského učitele, který byl v meziválečném období v úzkých přátelských osobních i vědeckých stycích s českými fyziky, člena Jednoty československých matematiků a fyziků, rodilého Pražáka, který „mluví bezvadně česky“ a „má úzké vztahy k této $z e m i{ }^{\text {“. }}$. Navzdory této charakteristice dokládající Fürthovu vědeckou kvalifikaci a naprostou politickou spolehlivost Žáček povolání Fürtha za profesora na Karlovu univerzitu nedoporučil, maje na zřeteli usnesení sboru děkanů v čele s rektorem univerzity. Své stanovisko k usnesení vyjádřil slovy: „I když je mi znám di̊vod tohoto usnesení, nepokládám je za správné a účelné, a kdyby skutečně v této obecnosti mělo býti praktikováno, dokonce za velmi nebezpečné pro vědeckou úroveň Karlovy university."V závěru Žáček zopakoval

\footnotetext{
20 AUK, f. PřF UK, k. 23, i. č. 209, MŠO zn. A-246.328/46-V/3. Obdobný dopis byl ministerstvem 23. listopadu 1946 zaslán děkanství Př́rodovědecké fakulty Masarykovy univerzity v Brně.

21 Tamtéž, děkanství PřF, č. j. 1627/46/47/C/Le, kopie.
} 
návrh, formulovaný již dřive společně s profesorem Trkalem, aby byl Reinhold Fürth ministerstvem pozván do Československa alespoň $\mathrm{k}$ několika přednáškám o pokrocích fyziky během několika posledních let. 22

Dodejme, že otázka profesorů bývalé Německé univerzity v Praze byla v akademických sborech obnovených českých vysokých škol diskutována hned po obnovení jejich činnosti po válce. Zmíněné stanovisko sboru děkanů fakult a rektora Karlovy univerzity zaznělo již ve schůzi 27. června 1945 v diskusi o úpravě styků s cizinou. Profesor Trkal, který zde reprezentoval Př́rodovědeckou fakultu, se tehdy zmínil o dvou osobách, jež působily před válkou na Německé univerzitě v Praze a projevily zájem o návrat do Československa: matematiku docentu Karl Löwigovi a astronomu profesoru Erwinu Freundlichovi. Postoj rektora Jaroslava Bělehrádka byl v zápise ze schůze shrnut slovy: „Snad by mohli se tito uchazeči uplatnit v čisté vědě, nikoliv však ve službě vysokoškolského učitele. Dr. Freundlich mohl by snad býti zaměstnán ve státni hvězdárně. Vyučováni však a výchova může býti svěreno výlučně rukám českým a za Čecha by bylo pokládati toho, kdo v r. 1910 byl české národnosti; [...]. Universita pak musí býti ústavem výlučně národním." $\mathrm{K}$ tomu přečetl dopis Erwina Freundlicha, který byl napsán anglicky, a dodal: „Už z toho di̊vodu nemůže býti profesorem na universitě, protože neumí česky. "Viktor Trkal následně konstatoval, že Freundlich je sice astronomem „evropského“ významu a obor astronomie je na Karlově univerzitě ,chabě obsazen“, s jeho povoláním přesto nemůže souhlasit ,už z toho důvodu, že by se z tohoto oboru stala država némecká" ${ }^{23}$

Ve schůzi děkanů 5. záŕí 1945 Viktor Trkal informoval, „že vyslanec Císař zaslal dopis, jímž se přimlouvá, abychom povolali profesory Fürsta [zjevně Fürtha], Freundlicha a Polivku [? L. W. Pollacka] na universitu. Rektor k tomu podotkl, že na universitě to nebude možné, bylo by to však možné při mezinárodni akademii.“24

Otázka německých vysokých škol (nutnost právní úpravy) a zahraničních učenců byla nastolena také při návštěvě rektora Bělehrádka u prezidenta Beneše, o které Bělehrádek referoval ve schůzi děkanů 27. června 1945. ${ }^{25}$

\section{Přírodovědecká fakulta Masarykovy univerzity}

Profesorský sbor Př́rodovědecké fakulty Masarykovy univerzity v Brně jednal o př́íisu Ministerstva školství a osvěty ve věci dopisu Guida Becka ve schůzi 16. prosince 1946. Na návrh profesorů fyziky Bohumila Hostinského a Josefa Zahradníčka se bez dalších komentár̆ů shodně usnesl, „že není vhodno, aby v zahraniči žijici fysikové-emigranti, uvedeni $v$ př́pisu Associacion física Argentina, kteři pưsobili pred válkou na nëmeckých vysokých školách ČSR, byli povoláni k vysokoškolskému působení v ČSR". Usnesení tlumočil ministerstvu děkan Přírodovědecké fakulty Masarykovy univerzity, profesor geografie František Vitásek v dopise z 31. prosince $1946 .{ }^{26}$

22 Tamtéž, Fyzikální ústav UK, č. j. 848/A, Žk/So.

23 AUK, f. AS UK, k. 43, i. č. 664, zápis o schůzi děkanů fakult University Karlovy, která se konala 20. června 1945 (dále jen zkráceně), s. 3. Repatriace a uplatnění pedagogů bývalých německých vysokých škol v poválečném Československu byly posuzovány také v souvislosti s jednáním o zřízení mezinárodní univerzity v Praze. Srov. AUK, f. AS UK, k. 45, i. č. 664, zápis o II. řádném zasedání akademického senátu, 31. 1. 1947, b. 5 (Plán mezinárodní university, ref. prof. Dr. J. Bělehrádek). K tomu podrobněji Z. PoustA, Jaroslav Císař, s. 274.

24 AUK, f. AS UK, zápis o schůzi děkanů, 5. 9. 1945, s. 6-7.

25 AUK, f. AS UK, zápis o schůzi děkanů, 27. 6. 1945, s. 5 a 7-8.

26 AKPR, f. KPR, k. 306, i. č. 1644/L, děkanství PřF Masarykovy univerzity v Brně, č.j. 2902/46, opis. 


\section{Jiné československé vysoké školy}

Doklady o korespondenci Ministerstva školství a osvěty s jinými vysokými školami v Československu v dané věci se zatím nepodařilo nalézt. Zdá se nicméně, že otázka byla předmětem jednání také na české Vysoké škole technické v Brně. Nasvědčují tomu slova tamního profesora fyziky Josefa Velíška v dopise Viktoru Trkalovi z 25. ledna 1946, v němž napsal: „Také jsme dostali od dra Q(!). Becka z Argentiny opis memoranda, které poslal p. presidentovi stran reservy vědeckých pracovniků t.č. v emigraci. Jest podivuhodné, že to přicházi právě až z Argentiny. S odpovědí si však víme rady. Patrně ve stejném smyslu odpovite také vy v Praze." Dikce sdělení napovídá, že postoj Vysoké školy technické v Brně $\mathrm{k}$ iniciativě byl rovněž odmítavý. ${ }^{27}$

\section{Vyrozumění Kanceláře prezidenta republiky}

Ministerstvo školství a osvěty informovalo Kancelář prezidenta republiky o stanovisku profesorských sborů vysokých škol dopisem z 28. února 1947. K dopisu připojilo kopie vyjádření obou profesorských sborů, včetně písemného návrhu profesora Augusta Žáčka, a dodalo, že názor profesorských sborů sdílí. ${ }^{28}$ Tím byla záležitost pro Kancelář prezidenta republiky žrejmě uzavřena.

Př́ípisem z 11. dubna 1946 pak ministerstvo sdělilo děkanství Př́írodovědecké fakulty Karlovy univerzity, že žádosti o pozvání profesora univerzity v Edinburghu Reinholda Fürtha nelze vyhovět, „protože se nezdá dost vhodným, aby profesor bývalé německé university v Praze přednášel nyní na Karlově univerzitě v Praze“.29

\section{Závěr}

Nikdo z uvedených německých fyziků se do Československa k trvalému pobytu nevrátil. Je nicméně možné nalézt doklady o dílčích vědeckých kontaktech (přinejmenším některých z nich) s československými fyziky v pozdějších letech. ${ }^{30}$ Skutečnost, že zmíněným fyzikům nebyl návrat do poválečného Československa umožněn (pokud o něj stáli), lze označit za politováníhodnou nejen z lidského hlediska, ale i z pohledu obnovy československé poválečné fyziky, nebot' šlo vesměs o osoby k Československu loajální a uznávané odborníky ve svém oboru. Do politických rozhodnutí přijatých bezprostředně po válce se ovšem nutně promítly zjitřené protiněmecké nálady a trpké válečné zkušenosti. Složitosti celé otázky

27 Masarykův ústav a Archiv AV ČR (dále MÚA), fond Viktor Trkal, k. 1, sign. IIb-1, Korespondence, J. Velíšek (strojopis).

28 AKPR, f. KPR, k. 306, i. č. 1644/L, MŠO č. A-39405/47-VI/5.

29 Tamtéž, MŠO č. A-104861/46-VI/3.

30 Srov. články Kurt SitTe, A Study on a contaminated cloud chamber, Časopis pro pěstování matematiky a fyziky 73, 1948, s. 31-40 (uvedená afiliace autora: Fyzikální laboratoř univerzity v Manchesteru); TÝž, Problems in the interpretation of cosmic-ray nuclear interactions, Czechoslovak Journal of Physics 9, 1959, s. 271-284. K publikaci prvního článku se váže dopis M. A. Valoucha V. Petržílkovi ze 14. 7. 1948, v němž Valouch píše: „Milý př́iteli, zasílám Ti v př́loze korekturu K. Sitteho s prosbou, zda bys laskavě mohl provést korekturu, abychom to nemuseli posílat do Anglie. Věc spěchá [...].“ MÚA, fond M. A. Valouch, k. 6, i. č. 337. Druhý článek byl souhrnem několika přednášek, které K. Sitte vykonal u př́ležitosti návštěvy v Praze v prosinci 1957 až lednu 1958; v závěru děkuje ČSAV za pozvání k návštěvě. 
si byl ostatně vědom i Guido Beck a naznačil to ve svém dopise. S časovým odstupem je ovšem možné si zároveň položit otázku, jak by se býval v př́ipadě návratu do poválečného Československa dále odvíjel osud kteréhokoli ze zmíněných německých fyziků?

\section{Dovětek o působení Guida Becka na Německé univerzitě v Praze}

O krátkém působení Guida Becka na Německé univerzitě v Praze existuje hodně nejasností. Cílem následujícího dovětku je upřesnění některých údajů na základě rešerše adekvátních pramenů v českých archivech.

Podle záznamů pražského policejního ředitelství se Guido Beck přihlásil k pobytu v Pra-

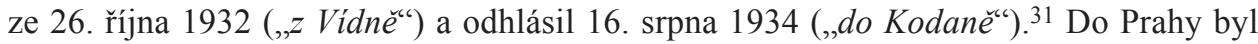
pozván ke konání hostujících přednášek (Gastvorlesungen) o „atomové fyzice“ na Přírodovědecké fakultě Německé univerzity v zimním a letním semestru školního roku 1932/1933 a znovu ve školním roce 1933/1934. Př́slušné návrhy předložili profesoři Philipp Frank a Reinhold Fürth. Profesorské kolegium fakulty návrhy ,jednomyslně a v̌rele“ podpořilo. Tehdejší Ministerstvo školství a národní osvěty s nimi souhlasilo s výhradou, že s tím pro ministerstvo nebudou spojeny žádné finanční výdaje. ${ }^{32}$

Do tištěných programů Německé univerzity v Praze se přednášky a semináře Guida Becka nedostaly. Mezi studenty i pedagogy vzbudily nicméně značný zájem, nebot' zahrnuly nejnovější poznatky jaderné fyziky a kvantové teorie. Promítly se i do vědeckých prací konaných na fakultě. ${ }^{33}$

31 NA, fond Policejní ředitelství Praha II - evidence obyvatelstva (PǨ II - EO), Beck Guido 1903.

32 AUK, f. NU, PřF, Protokoly ze schůzí profesorského kolegia (dále jen Protokoly), 1931/32, schůze 28. 1. 1932, b. 14; Protokoly 1932/33, schůze 26. 1. 1933, b. 12. David C. Cassidy v biografii W. Heisenberga k působení G. Becka na Německé univerzitě v Praze uvádí: „Beck’s assistantship with Heisenberg had already ended in early 1932 and could not be continued. [...] Bohr had secured funds for him to go to Copenhagen until Easter 1934, but it was only a temporary remedy. Throughout most of 1933, Bohr and Heisenberg sought other funding for him. By the end of the year they finally created a unique position for him at the German University in Prague with the combined support of Dutch, Danish, and Swedish foundations. Beck remained in Prague only a few years [...].“ David C. CAssidy, Uncertainty. The life and science of Werner Heisenberg, New York 1991, s. 322, též poznámky 40 a 41 ke kapitole 15. Obdobně Dieter Hoffmann - Mark WaLker (eds.), The German Physical Society in the Third Reich: Physicists between Autonomy and Accommodation, New York 2012.

33 Tyto skutečnosti zazněly jako pádný argument v žádosti profesorů Franka a Fürtha o povolení hostujících přednášek G. Becka „Z atomové fyziky“ také ve studijním roce 1933/1934 a o jejich řádné proplacení. V žádosti uvedli: „Im verflossenen Studienjahr hat [...] Herr Dr. Beck Vorlesungen auf dem genannten Gebiete und zwar über die Physik des Atomkerns und über Quantenchemie gehalten, die sowohl von zahlreichen Studierenden, als auch von Professoren und Assistenten der Fakultät besucht worden sind, was beweist, daß ein dringendes Bedürfnis nach solchen Vorlesungen hier besteht. Ein weiterer Erfolg der Tätigkeit von Herrn Dr. Beck besteht darin, daß er durch seine Vorlesungen und die sich daran anschließenden Seminarübungen wissenschaftlich befruchtend auf eine Reihe von jungen Forschern gewirkt hat. So ist unter anderem in Zusammenarbeit mit Herrn P. Wenzel seine Arbeit über die sogenannte kohärente Streuung der $\gamma$-Strahlen und in Zusammenarbeit mit Herrn Dr. K. Sitte eine Arbeit über die kontinuierliche $\beta$-Strahlung entstanden, die demnächst in physikalischen Zeitschriften erscheinen werden und geeignet scheinen, diese bisher rätselhaften Vorgänge einigermaßen aufzuklären. Auf Grund dieser Erfolge von Herrn Dr. Beck in Unterricht und Forschung im verflossenen Studienjahr halten es die Unterzeichneten für höchst wünschenswert, daß Herr Dr. Beck der Universität auch im kommenden Studienjahr erhalten bleibe und stellen daher den Antrag, das Ministerium möge die Abhaltung der Vorlesungen über Atomphysik auch für das kommende Studienjahr bewilligen. Da Herr Dr. Beck jedoch weder Vermögen besitzt, noch über sonstige Einkünfte verfügt, wäre es nötig, daß seine Tätigkeit entsprechend honoriert würde. Die Unterzeichneten sind sich zwar dessen bewußt, daß die derzeitige Situation der Staatsfinanzen die große Sparsamkeit erfordert, anderseits ist jedoch zu berücksichtigen, daß auf diese Weise 
Vzápětí po zahájení přednášek na Německé univerzitě v Praze podnikl Guido Beck kroky k dosažení pevnějšího postavení než jen hostujícího přednášejícího. V zimním semestru 1932/1933 požádal o nostrifikaci diplomu doktora filozofie z univerzity ve Vídni; jeho žádost byla obratem kladně vyřízena. ${ }^{34} \mathrm{Ke}$ konci roku 1933 pak podal žádost o habilitaci na Př́rodovědecké fakultě. K posouzení žádosti byla 7. prosince 1933 ustanovena komise složená z profesorů: Hans Meyer (analytický chemik), Philipp Frank, Ludwig Berwald (matematik), Reinhold Fürth (fyzik) a Karl Wagner (fyzikální chemik). Ve schůzi profesorského kolegia 20. ledna 1934 předložila komise zprávu, která připuštění Guida Becka k habilitačnímu ř́zení doporučila. Dne 8. března se konalo habilitační kolokvium, 19. dubna habilitační přednáška a téhož dne, ve schůzi profesorského kolegia, bylo udělení venia docendi pro obor fyziky Guidu Beckovi jednomyslně schváleno. Výsledek habilitačního řízení byl děkanem fakulty obratem tlumočen Ministerstvu školství a národní osvěty, kde pak celá záležitost ustrnula. ${ }^{35}$ Do konce roku 1935 nebyla habilitace Guida Becka ze strany ministerstva potvrzena, navzdory urgenci provedené koncem roku 1934 z podnětu profesora Reinholda Fürtha. ${ }^{36}$ Váhavý a rozpačitý postoj ministerstva k habilitaci souvisel s informacemi, že Guido Beck nehodlá v Československu zůstat a uvažuje o odjezdu do Ameriky nebo Sovětského svazu. ${ }^{37}$ Pod tlakem existenční nejistoty Guido Beck Prahu opustil. ${ }^{38}$

durch eine relativ geringfügige Aufwendung die physikalische Forschung in diesem Staate wesentlich gefördert werden kann.“ AUK, f. NU, PřF, Děkanát, 1933, k. 11, Zl. 601 (př́ípis k ministerstvu, 30. 5. 1933, podepsáni Frank a Fürth, projednáno ve schůzi profesorského kolegia 31. 5. 1933).

34 AUK, f. NU, PřF, Protokoly, 1932/1933, schůze 7. 12. 1932, b. 20.

35 AUK, f. NU, PřF, Protokoly, 1933/1934, schůze 7. 12. 1933, b. 11; schůze 25. 1. 1934, b. 3; IV. schůze 8. 3. 1934, před body programu; schůze 19. 4. 1934, před body programu.

36 AUK, f. NU, PřF, Protokoly, 1934/1935, schůze 6. 12. 1934, b. 11; pokračování II. schůze 10. 12. 1934, b. 8. V ř́ijnu 1934 podal žádost o habilitaci z fyziky na Př́rodovědecké fakultě Německé univerzity v Praze také Kurt Sitte.

37 Ve sdělení děkana fakulty, které bylo připojeno k zápisu ze schůze profesorského kolegia 5. prosince 1935, bylo konstatováno, že ministerstvo oznámilo děkanátu ve věci habilitace Dr. Becka následující stanovisko: „Es wurde erhoben, dass der für die Habilitierung beantragte Dr. Quido Beck am 16. August 1934 nach Kopenhagen abgereist ist, von wo er nach Amerika, bezw. nach Sowjet-Russland, weiterzureisen beabsichtigt. An eine Rückkehr in die čsl. Rep. denke er angeblich nicht. Das Min. f. Sch. u. Volks. hält daher die Angelegenheit für gegenstandslos und stellt die vorgelegten Beilagen zurück.“V zápisu ze schůze k tomu bylo dodáno: „Nach Rücksprache mit den Herrn Prof. Frank und Fürth ist beabsichtigt, zunächst die Stellungnahme Prof. Becks selbst einzuholen, bevor weitere Schritte beim Min. unternommen werden. Die Absichten Dr. Becks sind uns nicht bekannt, sind aber auch bei der Bestätigung der venia legendi nicht massgebend, da die venia dozendi nicht ununterbrochen ausgeübt werden muss."AUK, f. NU, PřF, Protokoly, 1935/36, schůze 5. 12. 1935, sdělení děkana, b. 9 .

38 Guido Beck v jednom pozdějším ohlédnutí uvedl, že krátce po odchodu do Kodaně v roce 1932 dostal pozvání pracovat v Praze. Zde však začal mít posléze politické problémy, proto odjel do USA, kam byl pozván jako hostující profesor na Kansaskou státní univerzitu. Pak dostal nabídku z Ruska na výuku fyziky na univerzitě v Oděse, kam odjel v roce 1935. <http://www.canalciencia.ibict.br/notaveis/livros/guido_beck_53.html?> (16. 1. 2018). 


\title{
EMILIE TĚŠÍNSKÁ
}

\section{Die Frage der Rückkehr von Physikern deutscher Nationalität in die Tschechoslowakei nach dem Zweiten Weltkrieg}

\author{
ZUSAMMENFASSUNG
}

In einem Brief vom 29. Juni 1946 wandte sich Professor Guido Beck, der damals an der Universität Cordoba in Argentinien tätig war, an den Präsidenten der Tschechoslowakischen Republik hinsichtlich der Rückkehr von fünf Physikern deutscher Nationalität in die Tschechoslowakei und der Verwendung ihres wissenschaftlichen Potentials in der Lehre an den tschechoslowakischen Hochschulen nach dem Zweiten Weltkrieg. Es handelte sich namentlich um Philipp Frank, Reinhold Fürth, Georg Placzek, Marcel Schein und Kurt Sitte, also um Personen jüdischen Bekenntnisses, die durch ihren Geburtsort, ihr Studium oder ihre berufliche Laufbahn mit dem Gebiet der Zwischenkriegstschechoslowakei und der Deutschen Universität Prag verbunden waren und zur Zeit der Briefabfassung im Ausland tätig waren. Die Präsidialkanzlei leitete den Brief G. Becks zwecks Stellungnahme an das Ministerium für Schulwesen und nationale Aufklärung weiter, welches den Standpunkt der Professorenkollegien der tschechoslowakischen Hochschulen einholte. Ihr Standpunkt zur Berufung der genannten Physiker an tschechoslowakische Hochschulen war durchweg ablehnend. Die Aufnahme von Vorlesenden an die tschechoslowakischen Hochschulen war nur bei Personen möglich, die sich bereits 1910 zur tschechischen Nationalität bekannt hatten bzw. über Tschechischkenntnisse verfügten. Bei den genannten Personen wurde zudem auf den Umstand verwiesen, dass lediglich Reinhold Fürth seine Bereitschaft zur Rückkehr aus der Emigration bekundete. Von diesem Standpunkt der Professorenkollegien, dem sich auch das Ministerium für Schulwesen und nationale Aufklärung anschloss, wurde die Präsidialkanzlei in Kenntnis gesetzt. Weitere Schritte in Sachen Initiative G. Becks waren offenbar nicht mehr unternommen worden. Keiner der genannten deutschen Physiker kehrte nach dem Krieg in die Tschechoslowakei zurück, partielle wissenschaftliche Kontakte zu tschechoslowakischen Physikern in der Nachkriegszeit gab es jedoch. Guido Beck wurde 1903 in Liberec (Reichenberg) in einer deutsch-jüdischen Familie geboren. Nach Studium und Beginn der beruflichen Laufbahn im Ausland fand er in den Jahren 1932-1934 eine zeitweilige Zufluchtsstätte an der Deutschen Universität Prag. Auf Vorschlag der Professoren Philipp Frank und Reinhold Fürth wurde er hier mit Gastvorlesungen über Atom- und Kernphysik betraut. Seine Vorlesungen erfreuten sich großen Zuspruchs seitens der Studenten und Pädagogen der Fakultät, in die gedruckten Vorlesungsverzeichnisse indes fanden sie keine Aufnahme. Ende 1933 beantragte Guido Beck an der Naturwissenschaftlichen Fakultät der Deutschen Universität in Prag seine Habilitation in Physik. Das Habilitationsverfahren bestand er mit Erfolg und das Professorenkollegium der Fakultät sprach sich einstimmig für seine Habilitation aus. Das Ministerium für Schulwesen und nationale Aufklärung verzögerte jedoch die offizielle Bestätigung im Zusammenhang mit Informationen, wonach Guido Beck in die USA oder die Sowjetunion gehen wollte. Im August 1934 verließ Guido Beck die Tschechoslowakei. Aus der kurzen Zeit seines Wirkens an der Deutschen Universität Prag gingen mehrere gemeinsame Publikationen Guido Becks und des Assistenten des dortigen Physikalischen Instituts, Kurt Sitte, zur Kernphysik hervor.

Deutsche Übersetzung Wolf B. Oerter

\author{
Emilie Těšinská \\ Ústav pro soudobé dějiny $A V \breve{C R}$, v. v. i., Praha \\ tesinska@cesnet.cz
}

